\title{
La vida trascendente de las formas o las formas de lo sagrado
}

Actualidad del arte sacro en la tradición española del realismo místico.

Un concepto ampliado por la aparición de la imagen fotográfica

The Transcendent Life of Forms or the Forms of the Sacred. An Update on Sacred Art in the Spanish Tradition of Mystical Realism. A Concept Expanded by the Appearance of Photography

Javier Viver Gómez

https://doi.org/10.17979/aarc.2009.2.1.5043

Quisiera agradecer, en primer lugar, a los organizadores de este evento, el Colegio de Arquitectos y la Diócesis de Ourense, su amable ofrecimiento; especialmente quiero agradecer a Esteban Fernández-Cobián y a Eduardo Delgado la invitación a asistir al congreso. Y también, la presencia de don Luís Quinteiro, algo que para nosotros, artistas y arquitectos, resulta muy gratificante, así como, por supuesto, la de todos ustedes, que están aquí asistiendo a estas sesiones y a los debates que se están celebrando.

La verdad es que me encuentro un poco fuera de mi medio. Yo soy artista y me manejo bien con las formas, pero no estoy acostumbrado a dar conferencias. Por eso, lo que voy a intentar hacer es una reflexión sobre una serie de intuiciones mías. El trabajo creativo se suele realizar en un plano que no es puramente conceptual, aunque luego intentemos conceptualizarlo. $\mathrm{Y}$ voy a hacer ese esfuerzo de intentar concretar y conceptualizar una serie de intuiciones en relación con la iconografía, y en concreto, con la iconografía religiosa. Voy a exponer un proceso - por decirlo de alguna formainconcluso; un proceso, un modo de afrontar la iconografía que me estoy planteando en la actualidad y que, de hecho, no ha finalizado todavía. Es algo que estoy experimentando, y podrán ver algunas imágenes de los resultados que estamos consiguiendo en el estudio.

\section{LA COMUNICACIÓN EN EL ARTE}

El otro día, Eduardo Delgado me enseñaba una representación de la Virgen con el Niño en sus brazos, en su seno, que yo había hecho cuando estaba estudiando quinto de carrera (Fig. 1). Y me llamó la atención volver a ver esa imagen, porque se encuadraba dentro de un discurso que tenía relación con los proyectos de Jorge Oteiza. En aquel momento me interesaban muchísimo las propuestas de imaginería religiosa que había hecho Oteiza. Y esas formas, que eran tremendamente sutiles, casi de especialistas, estaban rozando la abstracción. Para que se hagan una idea, era una imagen vaciada, esculpida en negativo y luego positivada. De tal modo que lo que te encontrabas era una especie de hornacina pero que no tenía nada que ver con una hornacina. Era un hueco, una especie de gruta en la que se incrustaba un gran cuerpo que era una representación de la Madre e integrado en ese cuerpo estaba el Niño, finalmente a los pies de la Madre un santo se postra y los besa. Este discurso, a mí, en ocasiones me ha planteado una pregunta que pongo aquí sobre la mesa: el tema de la comunicación.

Un conocido realizador cinematográfico, Víctor Erice, exponía que no había nadie más sólo que un director de cine contemporáneo. Yo creo que a veces esto se puede aplicar también a la arquitectura, a la escultura. Es un tema que yo me planteo directamente 
con la cuestión de la iconografía, porque me parece que es un aspecto que quizá la modernidad tendría que replantearse. Yo, desde luego, con estos proyectos que les voy a mostrar, verán que me lo replanteo. De hecho, las propuestas que estamos realizando tienen una relación importante con la esencia del arte, que es la comunicación.

Dicho esto, me gustaría citar a Dalí (Fig. 2). Salvador Dalí, como saben, escribió su «Manifiesto Místico», de mística nuclear, decía él, en 1951. En una conferencia pronunciada en La Sorbona de París, Dalí, con un poco de ironía, confesó que estaba muy agradecido por encontrarse en el país más inteligente del mundo; pero que él procedía de un país irracional como España. Y comentaba que, precisamente por eso, cuando hubiera que llevar a cabo la revolución de la mística nuclear, Francia tendría un papel importante en la redacción de su Constitución, un papel didáctico, y a España le correspondería llevar a cabo esta revolución con su fe religiosa y con la belleza que forma parte de su naturaleza ${ }^{1}$.

Al margen del tono provocativo que siempre tuvo Dalí, me parece que la anécdota encuadra la cuestión. Últimamente nos vamos encontrando signos importantes - especialmente entre las generaciones más jóvenes- de una especie de interés general por lo religioso. Y me voy a explicar, porque viendo el panorama uno puede decir: —iQué insensatez está diciendo este hombre! Bueno, pues sin ir más lejos, ahora mismo se están celebrando distintas exposiciones sobre el realismo místico español que están provocando una auténtica conmoción entre artistas y críticos contemporáneos. Me refiero a Lo sagrado hecho real: pintura y escultura de 1600 a 1700, que se encuentra en The National Gallery (Londres); a la titulada El misterio de la fe: una mirada a la escultura española entre 1550 y 1750 celebrada en The Matthiesen Gallery (Londres); y a la exposición monográfica sobre el Greco realizada en el Museo del Palacio de Bellas Artes de México.

$Y$ esto es un signo.

Fig. 1. Javier Viver, Virgen con Niño (c. 1992).

Fig. 2. Francesc Català-Roca, Salvador Dalí (1953).

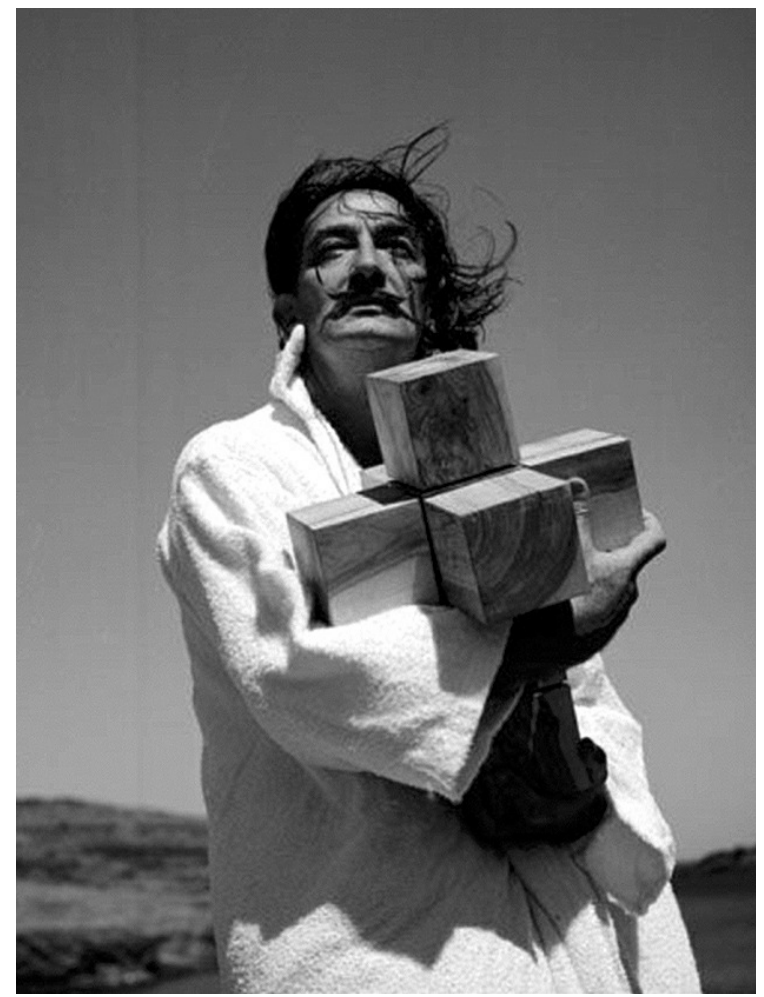




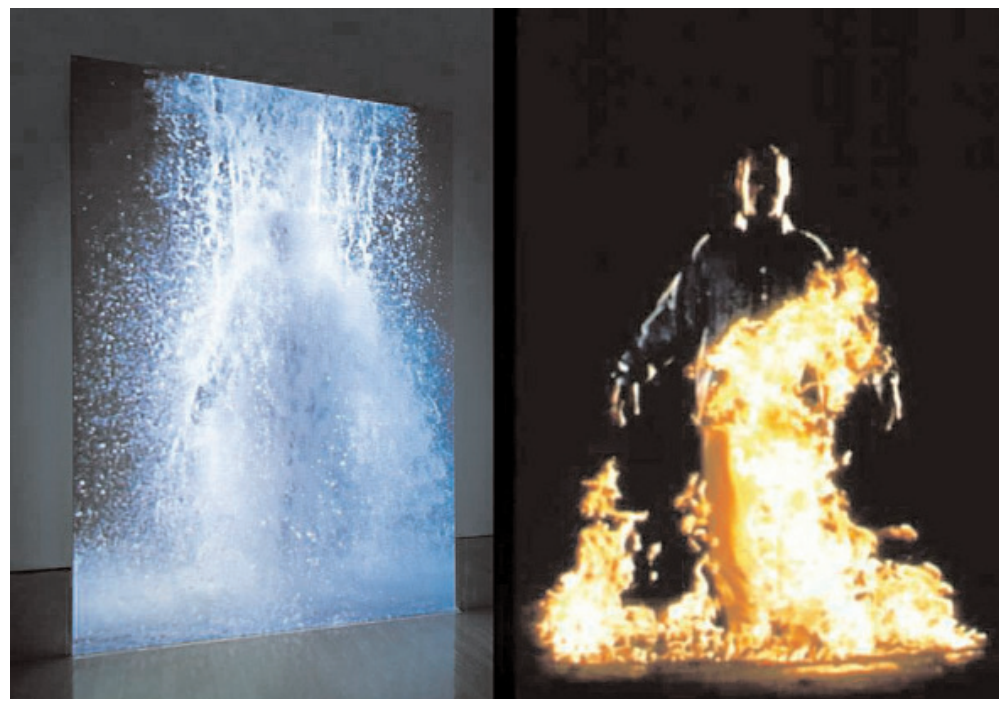

(En la página siguiente)

Fig. 4. La Santa Faz de San Silvestro, que se encuentra en la capilla privada del papa en el Vaticano.

Fig. 5. La Sábana Santa de Turín; detalle.

Fig. 3. Bill Viola, The Crossing (1996).

\section{A PROPÓSITO DE BILL VIOLA}

Pero me gustaría citar algunas obras concretas de autores contemporáneos. Traigo aquí el caso de Bill Viola, uno de los pioneros del videoarte. De origen iraquí, Viola, que se formó en la Universidad de Syracuse (Nueva York), hace un arte que toca directamente la cuestión religiosa. En ocasiones ha realizado obras de arte sacro, como el retablo hecho con vídeo que prepara en la actualidad para la catedral de St. Paul, en Londres.

Voy a narrarles una anécdota que nos puede ilustrar sobre lo que quiero contar. Viola estaba muy involucrado en las revueltas de los años sesenta y setenta, que planteaban, a través del uso de la televisión, una transformación social de carácter accionista, y que tenían una clara relación con el marxismo. Y sin embargo, llegó a sus manos un libro de poesías de San Juan de la Cruz. Se quedó impactado, y éste fue un punto de inflexión en su obra. Le sorprendió que, ante el encarcelamiento, un monje no respondiera con violencia, sino escribiendo poesía, escribiendo el «Cántico Espiritual». Esto le dejó absolutamente desconcertado, y tomó conciencia de que para transformar la sociedad - lo cuenta casi con estas palabras - debía transformarse él primero. Y empieza una línea que ya no es accionista, sino que es puramente contemplativa: una transformación social por la contemplación.
Aquí tenemos una obra suya que he tenido la oportunidad de ver en varias ocasiones (Fig. 3). En ella se ve una pantalla que, por un lado, es una cascada purificadora de agua, y por otro lado es fuego. Son dos elementos que siempre están presentes en la obra de Bill Viola. Su caso es significativo, pero resulta que en las nuevas generaciones se produce un fenómeno parecido. Yo tengo unos amigos que acaban de producir un retablo de paneles de luz, un retablo de pantallas de plasma con escenas sobre el Antiguo Testamento. Y lo han producido de forma independiente. El otro día me contaba una amiga que está estudiando Bellas Artes, que en clase un chico presentó con toda naturalidad - y según me contaba, no era un alumno que se distinguiera precisamente por su faceta religiosa- una Ascensión en vídeo, que por lo visto era sobrecogedora. Otro amigo videoartista está haciendo el doctorado sobre el videoarte en el templo cristiano. Y como éstos, nos vamos encontrando signos de algo que cada vez aparece con más naturalidad, y que me parece que nos puede hacer reflexionar.

De lo que quiero hablar hoy - $\mathrm{y}$ esto me ha servido de introducción - es de la importancia que tienen la fotografía y el cine como medios que pueden ser utilizados en la iconografía cristiana. Y esto no es una cuestión sólo técnica o funcional, sino consecuencia de la estrecha conexión que existe entre la imagen fotográfi- 

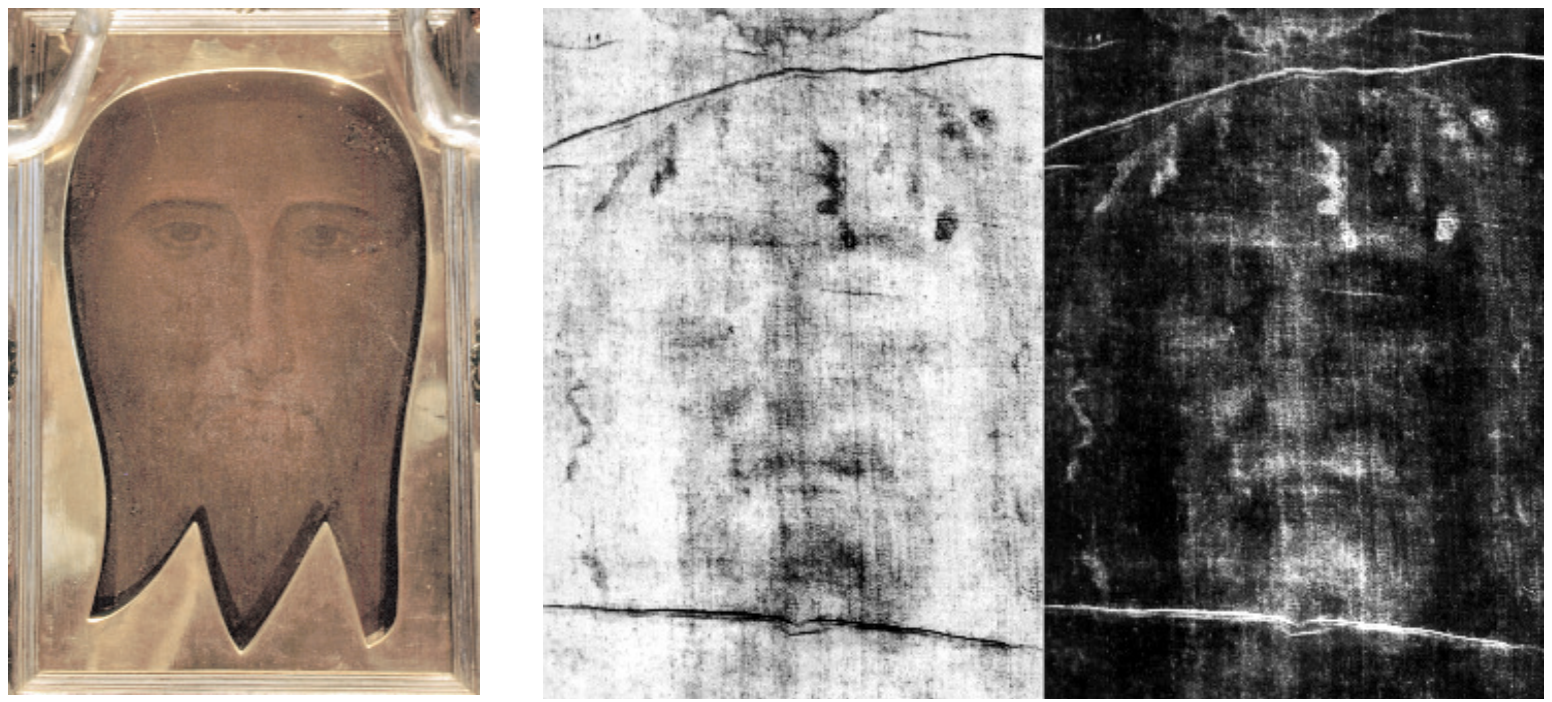

ca y el icono. Como trataré de mostrar, ambas participan de la misma naturaleza. Así que ésta es una cuestión de estética de la imagen: la fotografía ha producido unos cambios tremendos en la iconografía, así que me gustaría hacer unas reflexiones sobre esta realidad. Lógicamente, voy a hablar del icono. Así que les mostraré unas imágenes y contaré algunos hechos relacionados con el icono que me permitan establecer vínculos con los procesos fotográficos.

\section{LA IMAGEN ACHEIROPOIETOS}

Definamos en primer lugar, qué entendemos por imagen aquerópita o más exactamente acheiropoietos (Fig. 4). La imagen así llamada es cualquier imagen realizada sin la acción del hombre $-o$ la pintura sin mano, podíamos decir-. Aunque hay imágenes acheiropoietos de distintas procedencias, de alguna forma todas ellas tienen relación - o aluden - a esa imagen que Verónica toma por contacto con el rostro de Cristo. Según cuentan los Evangelios Apócrifos, aquella joven mujer enjugó con su velo el rostro de Cristo camino al Calvario, quedando en él impresa la imagen de Cristo. Esta imagen hecha por contacto, sin la mano del hombre, debió, en su momento, ofrecer una fascinación muy grande.

Veamos otra imagen acheiropoietos: la Sábana Santa de Turín, la síndone (Fig. 5). En este caso, es una imagen que se ha formado de una manera claramente fotográfica, porque es un negativo hecho mediante un proceso químico por el contacto con el cuerpo de un hombre crucificado. Tal como sucede en la fotografía, las hondas de luz queman la superficie fotosensible ${ }^{2}$. Todo lo que en el paño estaba en contacto con el cuerpo tuvo ese proceso de combustión, que no es fácil de determinar en qué consiste. Pero esta misteriosa y enigmática imagen nos ofrece una representación fotográfica de Cristo, una supuesta imagen fotográfica del cuerpo de Cristo, del rostro de Cristo. Esto, decía, debió de fascinar en la antigüedad: poder ver el rostro de Cristo. De hecho, en toda la Iglesia comenzó una nueva tradición iconográfica inspirada en la imagen acheiropoietos. Un nuevo canon para los pintores. Se produjeron muchísimas copias imitando esas imágenes acheiropoietos. Pero muy pronto la pretensión de representar al Cristo histórico, el rostro histórico de Cristo, dejó paso a una representación más teológica del icono, en la medida que éste trataba de hacer visible lo invisible. Si Cristo era la imagen de Dios invisible, el icono ofrecía este salto, un puente que le permitía convertirse en sacramental: hacía posible la encarnación de lo sobrenatural, el fenómeno hierofánico.

El otro día se comentaba en una de las sesiones que se necesitaba un cierto ayuno de la vista para pintar iconos $^{3}$. Un ayuno de la vista que permitiese acceder, no a 
illum in tabula per radios Solis, quàm in calo contingit: hoc eft, $f_{1}$ in colo fupcrior pars delıquiũ patiatur, in radiis apparcbit inferior deficere,vt ratio exigit optica.

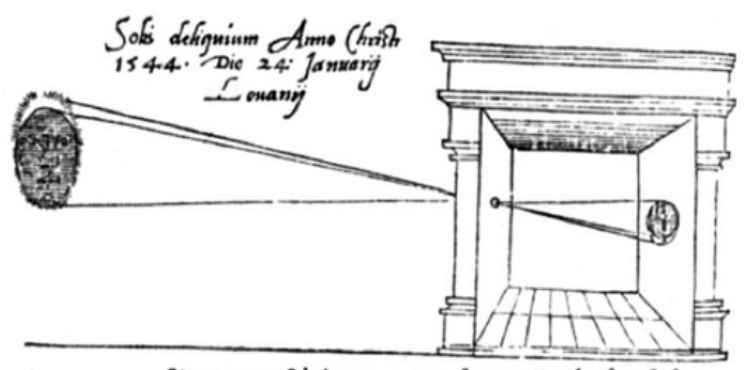

Sic nos exact c̀ Anno.1544. Louanii cclipfim Solis obferuauimus, inuenimuś́; deficere paulò plus ą dex. tantem, hoc eft. ro.vncias fiue digitos vt noftriloaun.

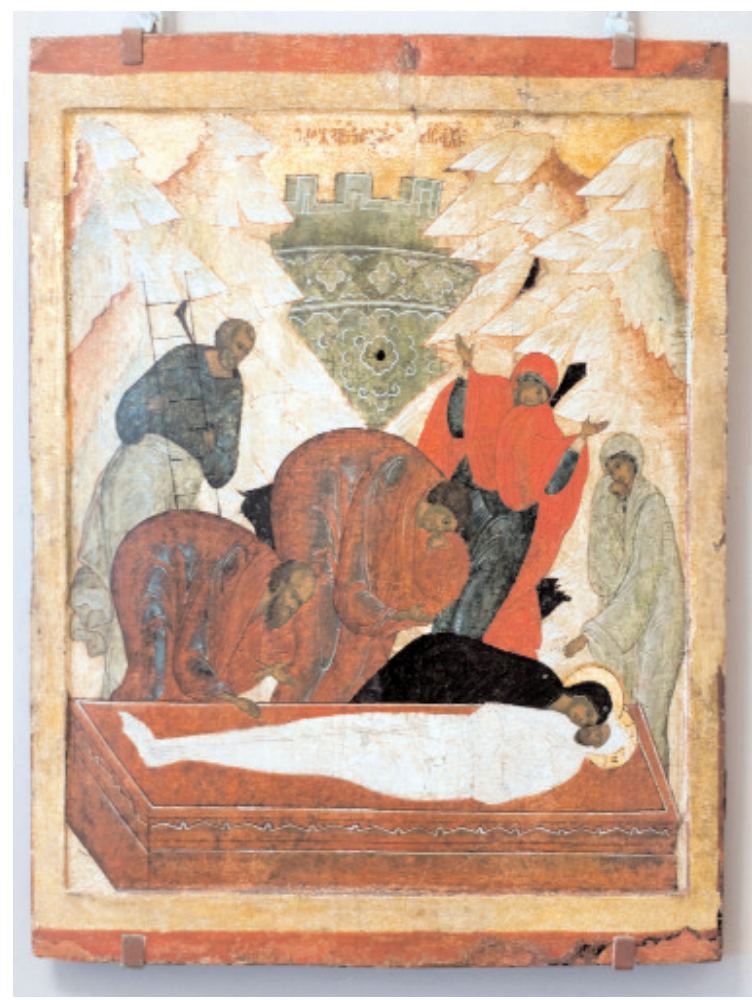

Fig. 06. Escuela de Pskov, Icono del Entierro (s. XVI).

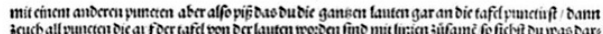

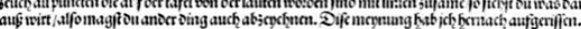

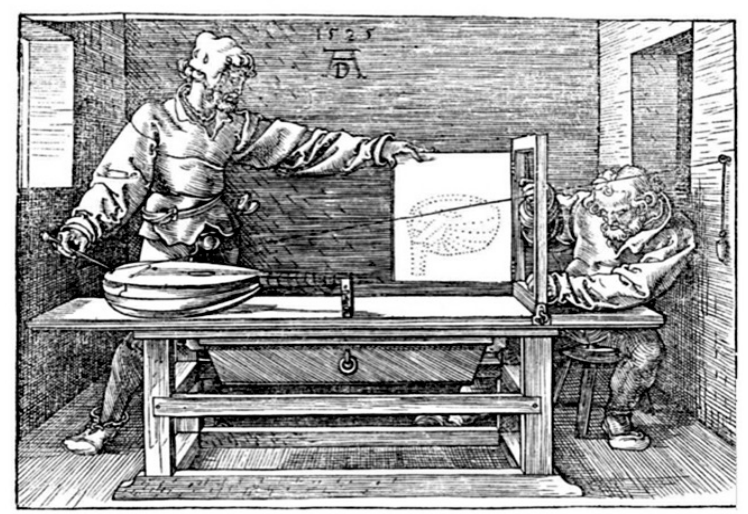

Fig. 7. Alberto Durero, La perspectiva inversa (1525).

la superficie o a la epidermis de las cosas - a las apariencias_-, sino a una capa posterior. Y éste es un concepto muy importante. Se ha puesto aquí de manifiesto pues, el carácter iconográfico, el carácter sacramental, que es esencial en el arte sacro.

Claro, enseguida comprendemos que la imagen tenía el peligro de llegar a ser un objeto de adoración en su aspecto material; y con ello surge el problema iconoclasta. La controversia iconoclasta fue resuelta en el II Concilio de Nicea (787), aceptado tanto en Oriente como en Occidente, afirmando la validez de los iconos y fundamentándolos en la Encarnación ${ }^{4}$. Si Cristo se había encarnado, había asumido todo lo humano, había asumido la naturaleza humana, y por lo tanto, era posible la imagen con esa doble dimensión: visible e invisible.

A la vez, el peligro de idolatría motivó el desarrollo de ciertos recursos de distanciamiento. Frente a la tradición clásica, la nueva pintura de iconos recelaba del naturalismo, proclamando lo que Pável Florenskij ${ }^{5}$ denominó — en pleno siglo XX-perspectiva inverti$d a$, como la manifestación más elocuente del espacio eterno $^{6}$. El artista inspirado en la tradición de la pintura sin manos debía desarrollar el ayuno de los ojos para entrar en otra lógica diversa de la mundana e inmediata, y de esta forma, disponerse a recibir el don de la presencia sobrenatural en el icono. Aquí ven algunos casos de perspectiva invertida, en la que el punto de vista no 


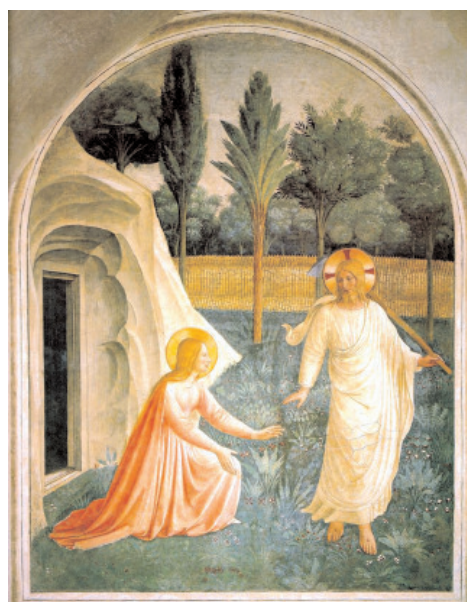

Fig. 8. Fra Angelico, Noli me tangere (c. 1437/46).

parte del espectador sino del cuadro. Es el icono el que le mira a uno y no a la inversa. Por eso las líneas de fuga se dirigen hacia nosotros, como en el féretro de Cristo en este icono del siglo XVI (Fig. 6).

\section{LA TRADICIÓN ICONOGRÁFICA EN OCCIDENTE}

Pero así como Oriente siguió - y sigue - muy fiel a la tradición del icono, Occidente comenzó una nueva vía de interpretación del icono que tiene mucha relación con la fotografía. Porque la pintura de Occidente está basada en la perspectiva monofocal, al igual que la cámara oscura, que es el antecedente de la fotografía. El desarrollo de la perspectiva monofocal y la cámara oscura tienen un recorrido paralelo a partir del siglo XIII (Fig. 7). Esta nueva vía llevó hasta el extremo la doctrina encarnacionista del II Concilio de Nicea: si Cristo había asumido la naturaleza humana, todo lo humano era susceptible de convertirse en escenario de lo divino. Así, lo que en Oriente se consideró como una intromisión intolerable del naturalismo pagano, en Occidente se entendió como la asunción cristiana de todo lo humano. Dios se hacía visible en el gesto del hombre y a través de los sistemas de visión del hombre.

Sin embargo, la nueva vía, aplicada al icono de Cristo o la Virgen, volvía a encontrarse con el problema de la inmediatez. Los retratos renacentistas de la Señora asumieron los usos de la época, representándola al modo de las princesas contemporáneas. El espacio reproducía la ilusión de la perspectiva. El cielo abandonaba la eternidad del fondo dorado para representar el paisaje o la ciudad de los hombres. Se hacía necesario, por tanto, la utilización de recursos de abstracción y distanciamiento entre la imagen sagrada y la realidad contingente que le permitiera trascender hacia lo invisible sin quedarse en la realidad contingente. Fra Angélico (1390/1455) tamizó de luz y piedad ese naturalismo demostrando la validez del nuevo planteamiento (Fig. 8). Aquí ven unas rocas que son tremendamente abstractas y nos sitúan en el ámbito ideal de la representación por el tratamiento del paisaje. Occidente abría así una vía de sacralización de lo secular, que no llegaría a su plenitud hasta el desarrollo de la fotografía y la cinematografía, una vez que los procesos químicos permitieron embalsamar las imágenes de la cámara oscura en placas emulsionadas.

Un momento decisivo en esta trayectoria fue el desarrollo de la nueva imaginería del siglo de oro español, consecuencia de los dictados emanados de la reforma tridentina. El barroco ofreció una solución admirable de encuentro entre el realismo y lo sobrenatural. En él, conviven el efecto naturalista con la abstracción provocada por la teatralización de las composiciones, el claroscuro y el color, creando a la vez una cercanía y un distanciamiento de gran fecundidad para el arte sacro. La mística española era imaginera, a diferencia de la protestante, y realista, frente a la ortodoxa. En ella, lo sobrenatural se encarnó mediante la visión revelada. Dios asumía la imagen natural y, en palabras de santa Teresa, se hacía presente entre los pucheros del bodegón barroco ${ }^{7}$. Estas son algunas imágenes también acheiropoietos de Zurbarán. El Greco y Zurbarán tienen muchísimas, dentro de la tradición naturalista (Fig. 9).

Otro ejemplo significativo, continuador de esta tradición, es el que ofrece la escultura que ensayó Antoni Gaudí (1852/1926) en la Sagrada Familia (Fig. 10). Gaudí se planteó una imaginería realista trabajando con moldes de yeso tomados del natural, otro sistema acheiropoiético, realizado por contacto y sin intervención de la mano humana ${ }^{8}$. Fue un esfuerzo titánico. Vació la imagen de muchísimas personas, de niños que habían muerto en el hospital, o incluso de abortos. Gaudí planteó un reto importante, ya que el propio modelo tenía un valor iconográfico. A través de una correcta dirección de actores — tal como se hace en una película-, el mode- 


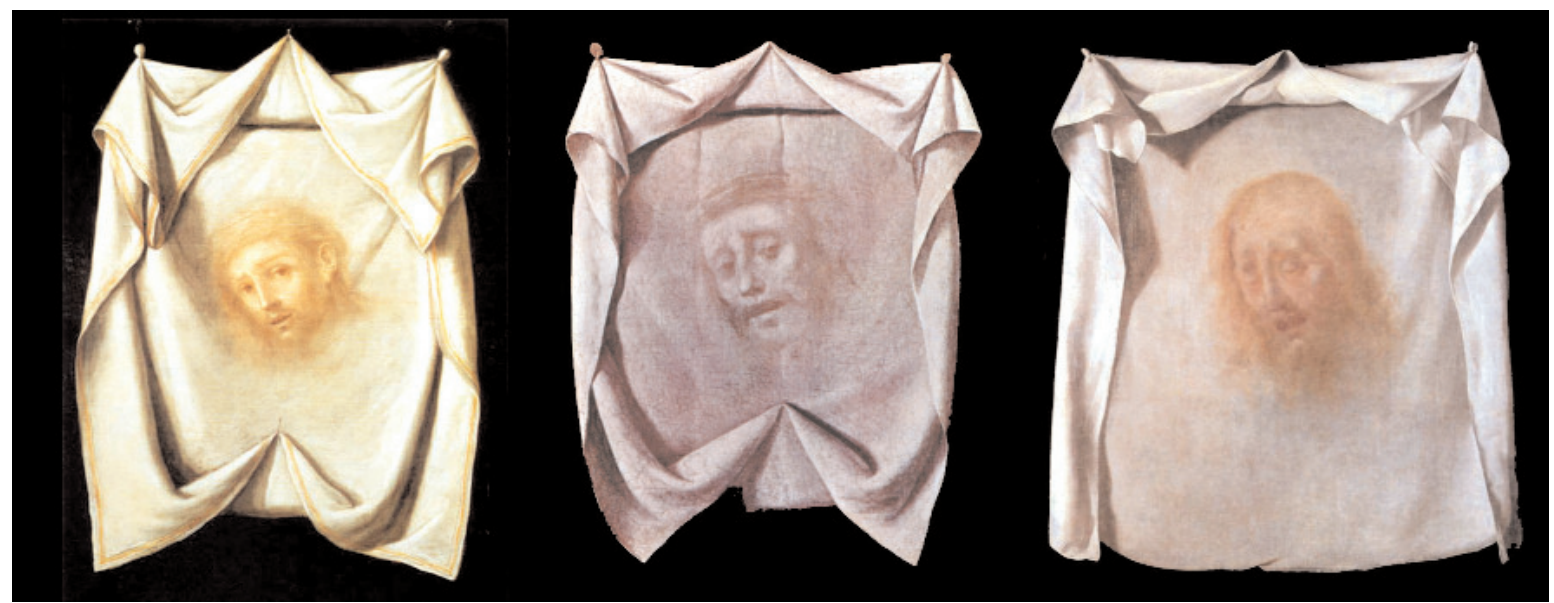

Fig. 9. Francisco de Zurbarán, Santa Faz (c. 1660), El lienzo de la Verónica (c. 1631/35) y El velo de la Veronica (1658/61).

lo debía ponerse en disposición de que allí apareciera lo sagrado, lo religioso, lo sobrenatural: exactamente de la misma forma a como lo hacían los pintores de iconos. Y esto ya no se hacía en una tabla, sino en el propio cuerpo del modelo: en la misma actuación debía producirse esa encarnación del misterio, el propio gesto del modelo se convertía en sacramental. Un intento - desde mi punto de vista - audaz, pero malbaratado en el proceso de copia y escalado en piedra que hicieron los canteros de la Sagrada Familia. Luego volveré sobre este proceso. De hecho, a mí me parece que lo más interesante de Gaudí son los procesos que plantea. Por ejemplo, todo el despliegue que hacía con espejos, de tal forma que creaba visiones telescópicas del modelo a través de espejos cruzados para poder obtener diferentes puntos de vista desde un mismo lugar de observación. Esta es una visión que tiene mucho que ver con la eternidad, con la visión multifocal del ojo eterno (Fig. 11).

\section{LA IMAGEN FOTOGRÁFICA Y CINEMATOGRÁFICA, Y LO SAGRADO}

El final de este recorrido, tal como he anunciado antes, llega con la aparición de la imagen fotográfica. Ésta supuso la realización literal de la antigua pretensión acheiropoietos: una imagen creada sin la intervención de la mano del hombre, como consecuencia de un proceso automático de desvelamiento de la luz invisi- ble. El mecanismo de la cámara producía un contacto directo del natural en la película, como consecuencia del reflejo de las ondas lumínicas en los objetos. Pero la luz, a su vez, se proyectaba en la pantalla, y ésta en la retina del espectador, realizando una transposición fidedigna del objeto representado.

El invento hacía posible una sacralización sin precedentes de la realidad temporal captada por el cinematógrafo. La imagen fotográfica era la encarnación de la luz en los objetos representados. La realidad se mostraba aurática, como han dado muestra de ello la obra de Dreyer (1889/1968), Tarkovski (1932/86), Bergman (1918/2007) y Val del Omar (1904/82); o más recientemente el propio Viola (1951) o Nathaniel Dorsky (1945) y su Devocional Cinema ${ }^{9}$, por poner tan sólo unos ejemplos. El cine añadió un elemento decisivo susceptible de ser sacralizado: la representación del tiempo, el acontecer. Lo cotidiano podía ser representado mediante la sucesión lumínica de los fotogramas en la película. El hecho hacía recordar, al mismo tiempo, el mismo origen de la liturgia orientada hacia la luz del sol naciente, imagen de Cristo resucitado. También la expresión de la vidriera gótica, como encarnación del Dios invisible, se hacía tremendamente actual con la aparición del cine.

Pero volvamos otra vez a Bill Viola. Aquí vemos otra obra titulada «Emergence» (Fig. 12). Como suele 


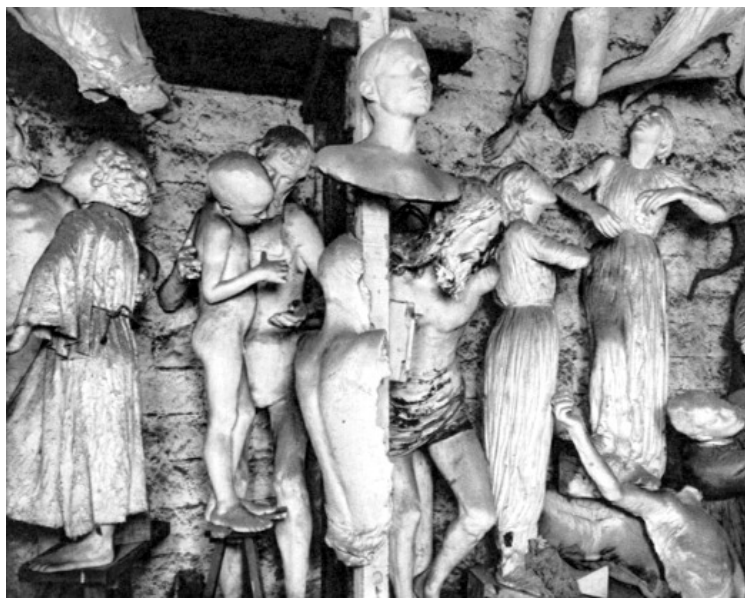

Fig. 10. Antoni Gaudí, vaciados para la Sagrada Familia.

suceder en cine, Viola trabaja con actores que deben interpretar un papel. En este caso, al artista le interesaba mucho que en este actor, que representaba a Cristo, se conjugasen dos imágenes: el Bautismo y la Resurrección. De tal forma que puso mucho hincapié en que el actor estuviera elevado como por la Gracia, por una fuerza exterior que tiraba desde su pecho hacia arriba. Una obra que, si han tenido la oportunidad de verla, es sobrecogedora. Tengo la experiencia de llevar a gente muy variada, y la gente sale de ahí muy emocionada. Algunos lo expresan explícitamente diciendo que esa obra crea un contexto de oración; otros hablan de que han estado en una situación de contemplación tremendamente espiritual.

En la obra de Viola vuelve a encontrarse esa dialéctica entre inmediatez que ofrece la imagen fotográfica y la necesaria distancia que permita la manifestación de lo sobrenatural. Y al decir imagen fotográfica también me estoy refiriendo a la imagen cinematográfica, en movimiento. Porque la fotografía muestra el rostro subjetivo de alguien concreto, muy cercano a nosotros, al que debemos trascender si queremos experimentar la manifestación de lo sagrado.

Viola resuelve el problema con una serie de estrategias de distanciamiento con respecto al modelo. En primer lugar el tratamiento de la luz, el maquillaje y la escenografía, crean una cierta distancia de la realidad,

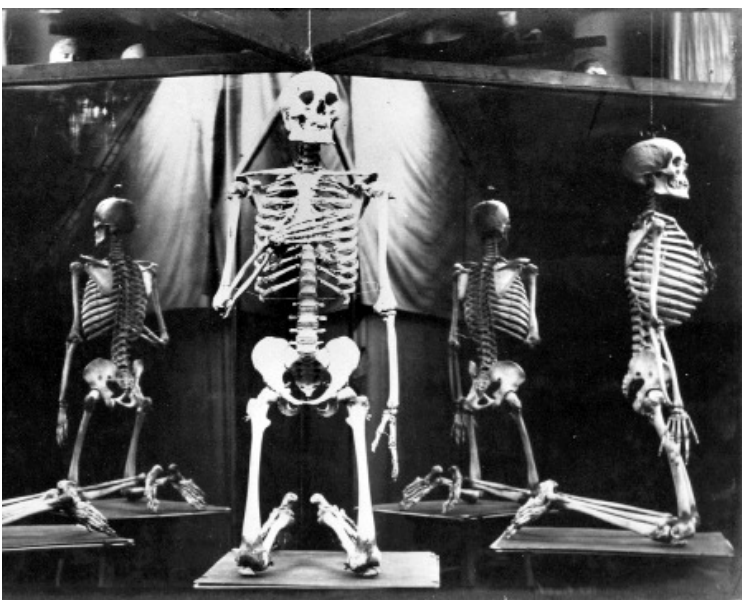

Fig. 11. Antoni Gaudí, esqueletos para la Sagrada Familia.

configurando una escenografía ficticia cercana a los escenarios de un plató. Una estrategia que el mismo Viola ha explicado en varias ocasiones. En algunos casos se inspira en el cuatrocientos italiano (con rocas y paisajes intencionadamente lunares) y en otros en el tenebrismo español (mediante la dramatización de la luz). Además desarrolla una teatralización explícita de las poses, haciendo depender la tensión de la obra de la interpretación de sus actores. Esta sobreactuación nos presenta un escenario irreal, en el que el espectador encuentra espacio para completar emocionalmente la actitud piadosa del actor. Pero sin duda, el factor más importante de todos es la ralentización de las imágenes. En efecto. Aunque «Emergence» está filmada a mil doscientos fotogramas por segundo, luego se muestra - como suele suceder en el cine convencional- a veinticinco fotogramas por segundo, de forma que lo que ha sido registrado con muchísimos fotogramas se puede extender en el tiempo, como en cámara lenta. Esto produce una forma de sacralización del tiempo, la sacralización del acontecer. Vemos ese tiempo representado; pero lo estamos viendo desde fuera del tiempo, porque el ritmo en el que contemplamos la escena no es nuestro ritmo real. Y de esta forma consigue introducir al espectador en otro ámbito que propicia la contemplación, tal como sucede en la pintura clásica, facilitando el nacimiento del cine devocional. 


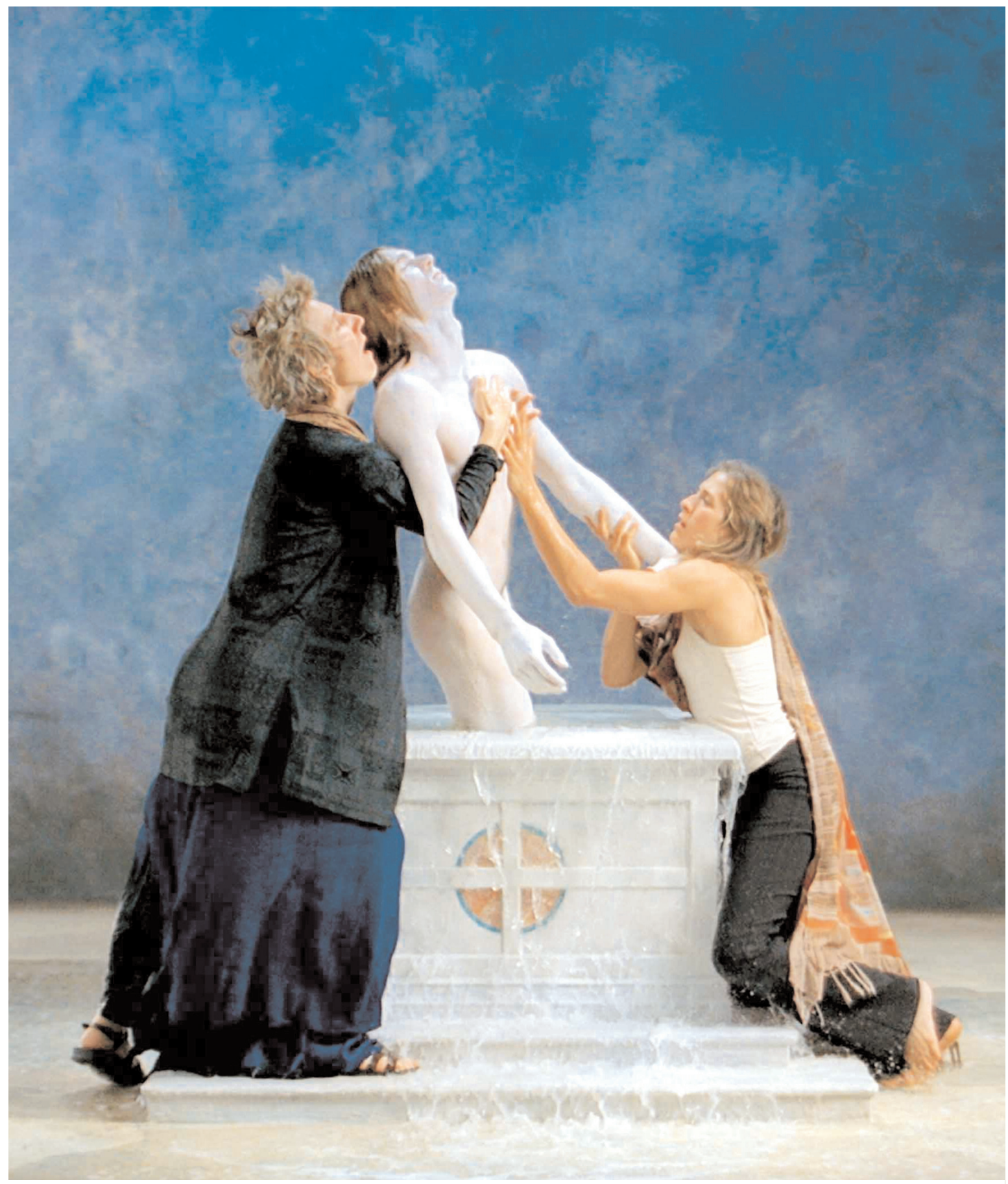

Fig. 12. Bill Viola, Emergence (2002); videoinstalación. 


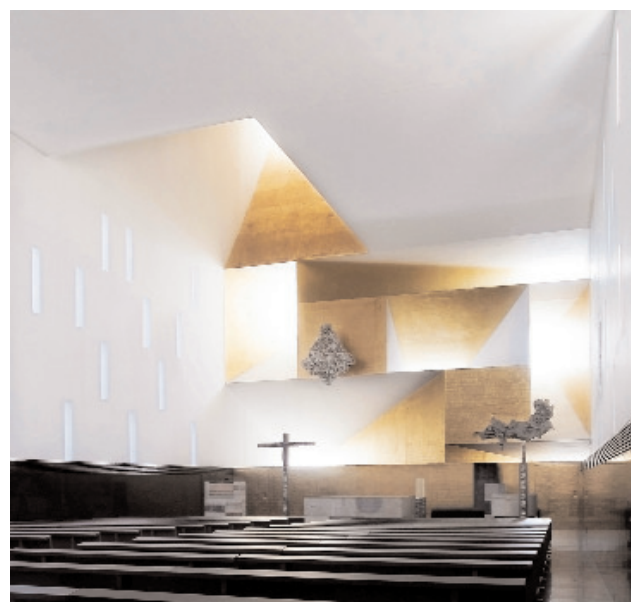

Fig. 13. Ignacio Vicens y José Antonio Ramos, Santa Mónica Rivas Vaciamadrid (Madrid, 1999/2009).

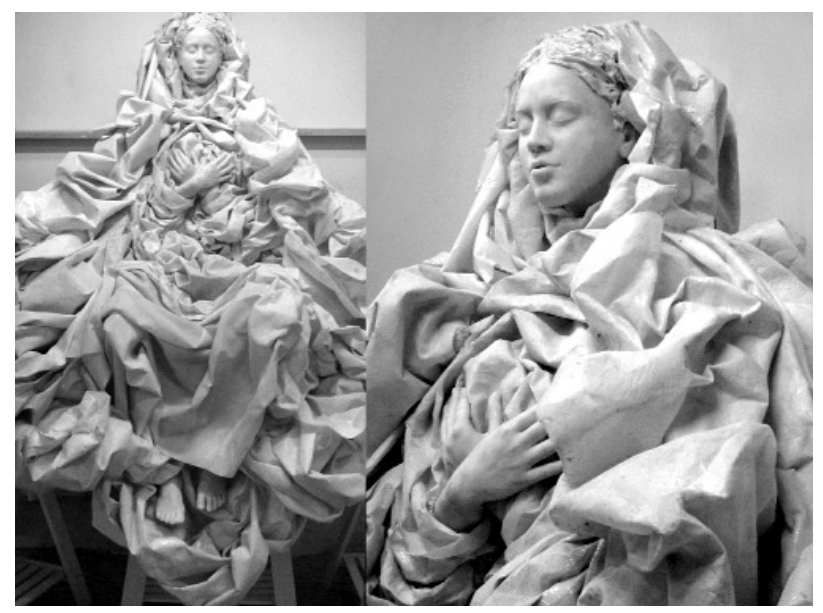

Fig. 14. Javier Viver, Santa María Vírgen, en la iglesia de Santa Mónica, Rivas Vaciamadrid (Madrid), 2008; detalle.
Paso a mostrar algunas imágenes de los procesos de creación en los que estoy trabajando, en relación con lo que acabo de contarles.

\section{PRIMER PROCESO: RIVAS VACIAMADRID}

En Rivas Vaciamadrid, la denominada ciudad sin Dios, a unos kilómetros de Madrid, se inauguró una parroquia dedicada a santa Mónica (Fig. 13). El arquitecto, Nacho Vicéns, me pidió una imagen de la Virgen María y otra de santa Mónica. Las imágenes se encuentran en ese clima en el que la levedad y la gravedad están en tensión, y las figuras, con todo el peso de sus ropajes, flotan en un efecto que es muy barroco (Fig. 14). Al comenzar a trabajar en este encargo estuve planteándome utilizar procesos fotográficos en la escultura; para ello hicimos vaciados del natural de distintas partes del cuerpo, trabajando con modelos que debían interpretar un gesto. Luego, esos cuerpos positivados eran envueltos en un ropaje de tela, tal y como hace el que confecciona un vestido. De tal forma que fuimos poniendo trozos de tela para luego consolidarlos con resinas. Santa Mónica aparece en posición horizontal llorando desconsoladamente por su hijo Agustín. Fue el primer intento de llevar a cabo el proceso que antes les he descrito.

\section{SEGUNDO PROCESO: LERMA}

Quiero mostrarles ahora el proceso completo en el encargo de una imagen de santa María para un monasterio de clarisas en Lerma. Porque me parece que ilustra lo que también sucede en el icono, y que los pintores de iconos expresan muy bien: que ellos no son los que hacen la obra, sino que es el Espíritu Santo el que toma posesión de la materia, de tal forma que el artista sólo realiza una labor instrumental; instrumental pero necesaria.

De la misma forma, en esta obra fue apareciendo lo sobrenatural, lo invisible a partir de una modelo de diecinueve años (Fig. 15). Con el arquitecto -Eduardo Delgado - y con las monjas hablamos sobre el tipo de escultura que teníamos que hacer. Yo hice el planteamiento - explícitamente - de la imagen acheiropoietos, y de trabajar con estos procesos para crear esa cercanía. Era un proyecto para una ermita, así que debía ser una mujer joven con la que pudieras entablar una conversación, un diálogo. Y entonces surgió esta idea. Yo propuse hacer una Virgen embarazada y sentada, en una actitud muy sencilla, a escala natural. La ermita, por lo tanto, debía ser simplemente un conjunto de sillas, y en una de ellas se sentaría la Virgen. Y esa instalación, digamos, estaba esperando ser completada con la incorporación de las monjas que se sentarían en corro alrededor de ella, unas en las sillas y el resto en el suelo. 

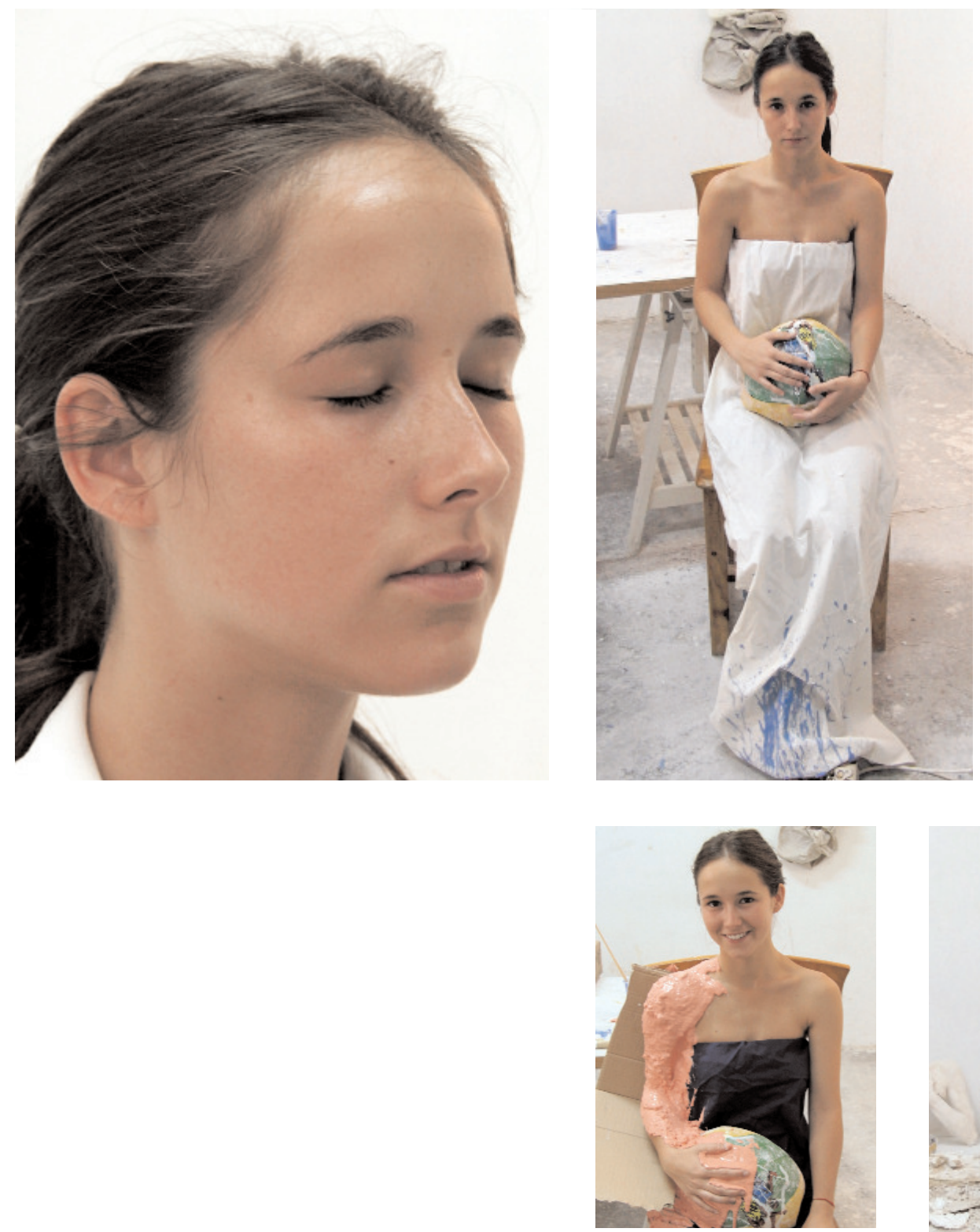

Fig. 15-18. (En las dos páginas) Javier Viver, Santa María Vírgen (2009); proceso. 

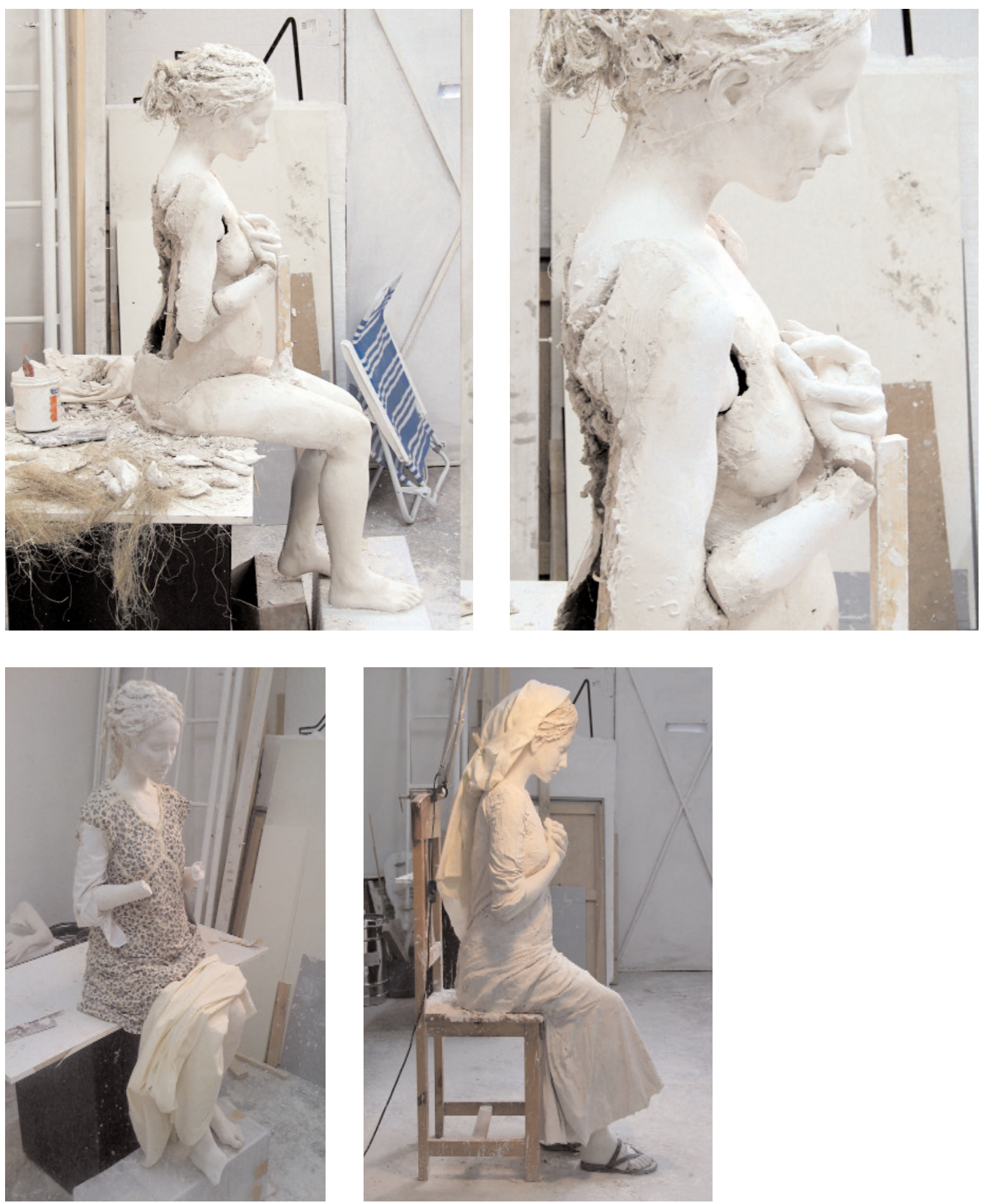


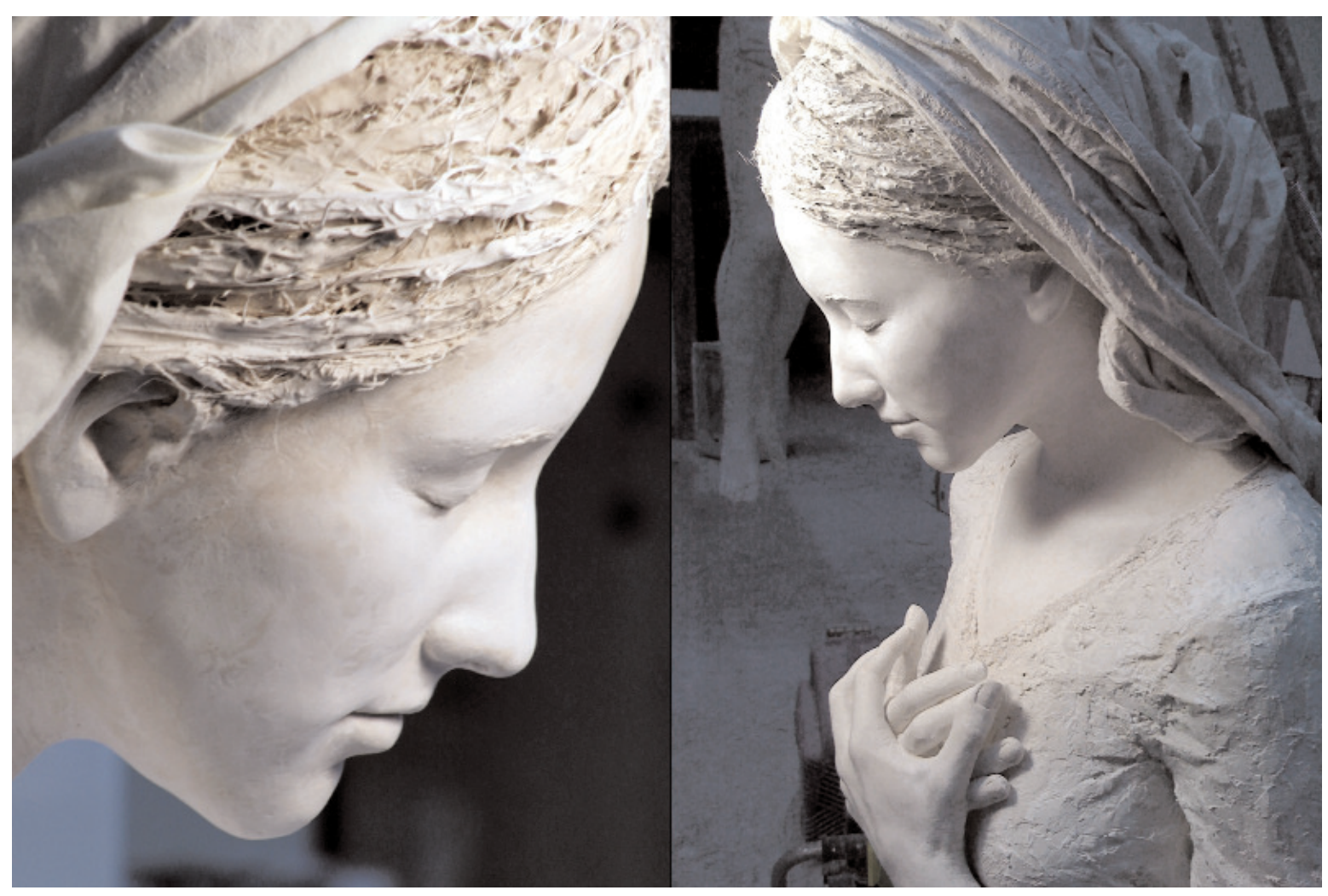

Fig. 19. Javier Viver, Santa María Vírgen (2009); resultado final. 


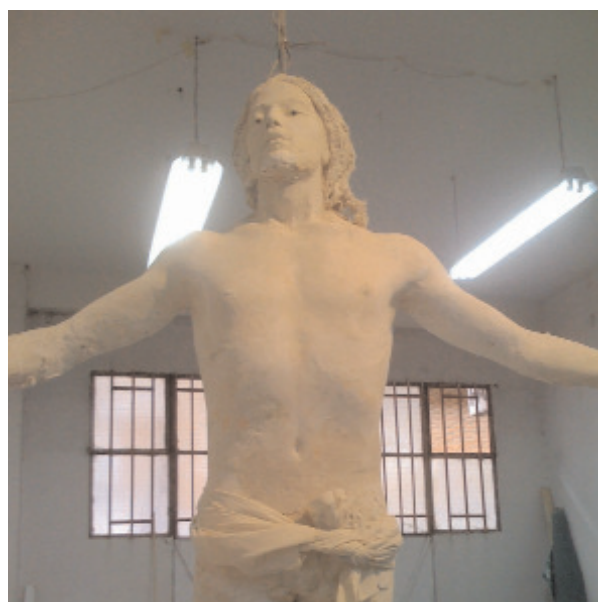

Fig. 21. Javier Viver, Cristo resucitado (2008).

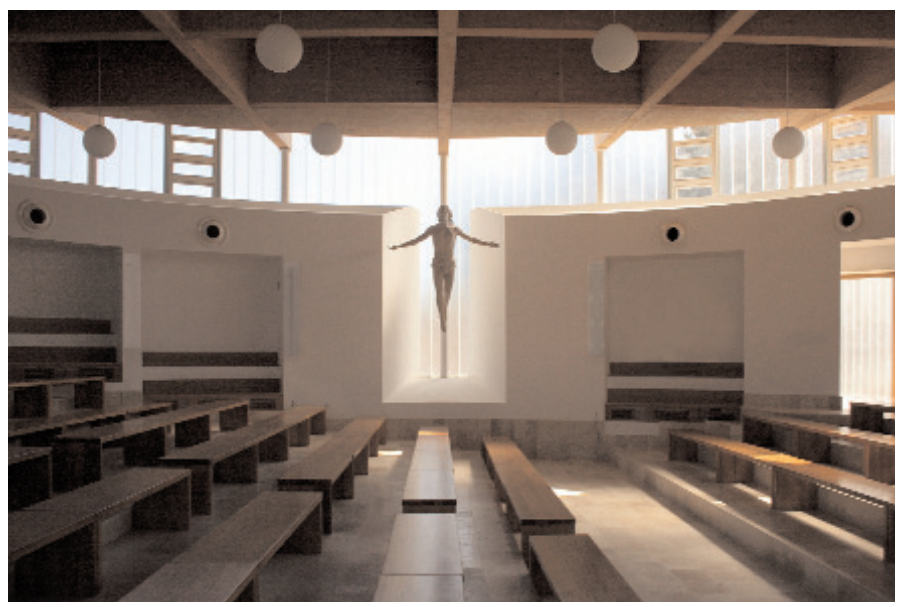

Fig. 20. Eduardo Delgado Orusco, convento de La Aguilera (Burgos, 2007-); capilla.
Aquí vemos el proceso, justo en el momento de empezar una sesión de vaciados. Se ve a la modelo con alginato, con el fin de obtener los moldes (Fig. 16). Fuimos sacando cada una de las partes del cuerpo de forma independiente (Fig. 17). Aquí se ve ya una imagen en la que se han ido integrando todas las formas y ya se empieza a ver el volumen. Una vez que teníamos el volumen del cuerpo, fuimos vistiendo ese cuerpo (Fig. 18). Y lo hicimos con tejidos que también consolidamos. Como es natural, la imagen va sufriendo modificaciones, y partiendo de esa inmediatez que ofrece la modelo, va adquiriendo también un grado de distanciamiento, un clima de oración que pueda permitir, hacer efectiva, la imagen religiosa, la aparición de lo sobrenatural, tal como afirma Evdokimov ${ }^{10}$ (Fig. 19).

Es muy significativo - y a mí me ha sorprendido bastante - ver lo que ha sucedido en el propio monasterio. Porque se ha producido un fenómeno que tiene que ver con el icono, y al que acuden muchos peregrinos. La propia imagen adquiere una presencia, y el peregrino tiene la necesidad de abrazarse a ella; o de echarse a los pies y al regazo de la madre. Y de hecho, es un fenómeno que sucede con cierta frecuencia con los visitantes que van al monasterio. También suceden otros fenómenos, como que las propias monjas sienten la necesidad de confiarle sus oraciones, hasta tal punto que incluso llegan a dejar papeles entre sus manos, en el hueco que existe entre las manos y el pecho.

Esta es otra imagen, también para el locutorio del mismo monasterio (Fig. 20-21). Se trataba de hacer un Cristo resucitado. Seguimos los mismos procesos de vaciado del natural, y aquí ven alguna imagen en el estudio, y aquí ya en el propio locutorio. Se puede ver cómo la imagen de Cristo es, de alguna forma, un símbolo de la luz que entra por la cristalera, que tiene una forma de tau. Pero está fundamentado en una experiencia muy vital de la luz: la imagen de Cristo hace presente la luz del Dios invisible.

\section{TERCER PROCESO: CIZUR MENOR}

Éste es un proyecto para una capilla del Colegio Mayor Bidasoa en Cizur Menor, cerca de Pamplona (Fig. 22). Me pidieron que representara un calvario, y se me ocurrió combinar dos tradiciones. Por una parte la tradición del calvario, y por otra, la de la cruz como árbol de la vida. Vaciamos un árbol y lo plantamos allí tal cual. Y en ese árbol está Cristo. Pero Cristo está glorioso, del tal forma que esta iconografía tiene un valor mistagógico. Lo que estamos haciendo es visualizar el misterio, el misterio sacramental; y en concreto, el misterio de la Pascua de Cristo que se celebrará en ese altar durante la Misa. La muerte y la resurrección están, de alguna forma, aunadas en Cristo, y esa imagen ofrece un icono de lo que sucede de forma invisible sobre el 


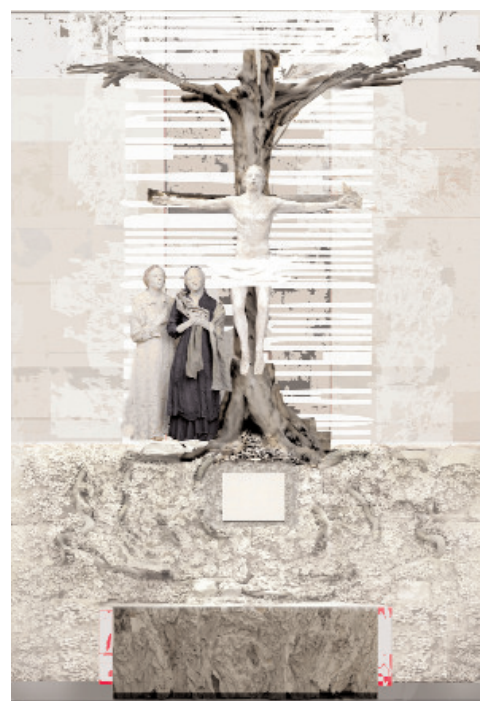

Fig. 22. Javier Viver, proyecto para Cizur menor (Navarra) (2009). altar. Todas las raíces de ese árbol florecen en torno al sagrario.

\section{CUARTO PROCESO: ALCALÁ DE HENARES}

Otro proyecto parecido - pero que todavía está pendiente de aprobación - se realizó para la iglesia de santa Úrsula, una iglesia de finales del siglo XVI, en Alcalá de Henares (Fig. 23). Pertenece a un convento del que sólo queda un maravilloso artesonado mudéjar y una talla de la Virgen de la escuela de Alonso Cano. Esta iglesia fue quemada durante la guerra civil. En realidad, lo que querían las monjas es que se volviese a realizar el mismo retablo que había existido. Pero como este conjunto tiene algún grado de protección patrimonial, no sé exactamente cuál, la Comunidad de Madrid no permitió que se hiciese una simple reproducción del antiguo retablo, por lo que se paró su reconstrucción.

Entonces me pidieron estudiar alguna solución que pudiera servir de puente entre las pretensiones de la Comunidad de Madrid y las monjas. Y lo que se me ocurrió fue la posibilidad de poner el antiguo retablo de una forma totalmente nueva. Esto se hace construyendo una imagen del retablo antiguo; en concreto, de la estructura del retablo barroco que fue quemado, revistiéndola de floraciones. Así, de las propias cenizas renace la vida, hasta tal punto que volvemos a encontrar la imagen de la muerte y de la resurrección.
Fig. 23. (En la página siguiente) Javier Viver, proyecto para Las Ursulas (Madrid) (2009); estado previo y propuesta.
Ese retablo sigue manteniendo esbozada la forma antigua y los órdenes clásicos; sin embargo, se ha convertido en un vergel, en un manto de floraciones sobre el que se sitúa la Virgen canesca y el sagrario.

Todavía no les he contado cómo estamos haciendo el proceso de las floraciones. Lo estamos haciendo en el taller, congelando flores y diversos vegetales directamente del natural, haciendo baños. Y entonces se empiezan a producir unas formas que mantienen todos los ritmos de las flores, pero que luego nosotros le damos una dirección ascensional, dado que en muchos casos la luz es cenital. De tal forma que todas estas floraciones se están levantando.

Para terminar, les anticipo un último proyecto. Me pidieron un cuadro de una imagen de la Virgen en su anunciación. Yo les propuse hacer una fotografía, de tal forma que en un plató haríamos una sesión fotográfica con dos modelos, y a través del vestuario y la iluminación trataríamos de conseguir algo parecido. Esta imagen sólo es una composición de distintos cuadros para explicarle la idea al comitente. Todavía está por ensayar cómo a través de la iluminación podremos crear ese equilibrio del que venimos hablando, entre la cercanía del realismo y una cierta distancia, siempre necesaria en la imagen sagrada.

Bien, pues esto es todo. Muchas gracias. 


\section{NOTAS}

(1) Cf. nota de Alain Bosquet en: Salvador Dalí, «Los cornudos del viejo arte moderno», Tusquets, Barcelona, 2000 (1956), pág. 19.

(2) Sobre este asunto comenta André Bazin: «Señalamos tan sólo que el Santo Sudario de Turín realiza la síntesis de la reliquia y de la fotografia» («¿Qué es el cine?», Rialp, Madrid, 2006, pág. 28). También Roland Barthes: «Tal vez sea esa extrañeza, esa obstinación, se sumerge en la sustancia religiosa en que he sido modelado; no hay nada que hacer: la fotografía tiene algo que ver con la Resurrección: ¿no podemos acaso decir de ella lo mismo que los bizantinos decían de la imagen de Cristo impresa en el Sudario de Turín, que no estaba hecha por la mano del hombre, acheiropoietos?» («La cámara lúcida», Paidós, Barcelona, 1989, pág. 145).

(3) San Doroteo habla del concepto de ayuno de los ojos en sus «Enseñanzas útiles para el alma»; cf. Paul Evdokimov, «El arte del icono. Teología de la belleza», Publicaciones Claretianas, Madrid, 1991, pág. 11.

(4) Norman Tanner, «Los concilios de la Iglesia», BAC, Madrid, 2003.

(5) Nota del editor. Pável Aleksándrovich Florenskij (1882-1937) fue un filósofo, matemático y religioso ruso. Su compleja figura intelectual y sus aportaciones a la literatura, la teología y la filosofía contemporáneas (especialmente a la filosofía de la ciencia) se han difundido sobre todo a partir de 1991, tras la apertura de los archivos de la KGB. Murió ejecutado por el régimen soviético, tras haber sufrido numerosos arrestos y haber pasado varios años en un gulag. En español, puede consultarse: Pável Florenskij, «La perspectiva invertida», Siruela, Madrid, 2005.

(6) El objetivo de las críticas de Florenskij era demostrar que la perspectiva de tradición renacentista no era más que una forma simbólica, tan legítima como la perspectiva invertida de los iconos rusos que él defendía. Vid. Pavel Florenskij, «La perspectiva invertida», Siruela, Madrid, 2005, pág. 92-96; escrito en 1919, fue publicado como: «Obratnaja perspektiva», Trudy po znakovym sistemam III 198 (1967), pág. 381-416. Más tarde, Erwin Panofsky volvería sobre estos argumentos en «La perspectiva como forma simbólica» (1924).

(7) Cf. Santa Teresa de Jesús, «Fundaciones» 5, 8.

(8) Según recoge Plinio el Viejo en su «Naturalis Historiae» (Libro XXXV, 153), el sistema se remonta a Lisístrato, que en el siglo IV a.C. inventó el vaciado del natural.

(9) Nathaniel Dorsky, «Devotional Cinema», Tuumba Press, Berkeley, 2003.

(10) Sobre el acto creador como teofanía puede verse Paul Evdokimov, «El arte del icono», cit., pág. 30-36.
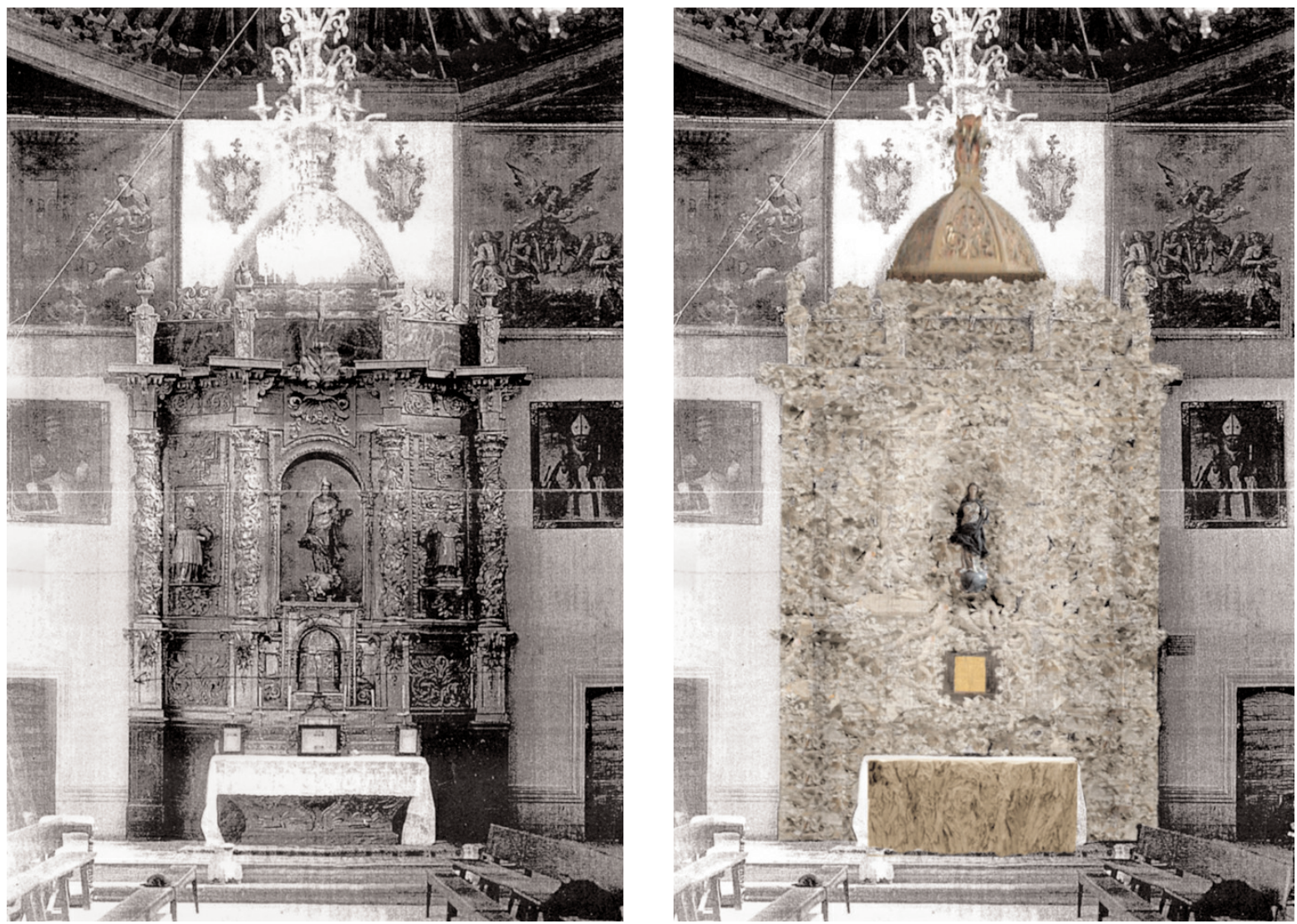